\title{
ЛІКУВАННЯ ІНФЕКЦІЙ ДІЛЯНКИ ХІРУРГІЧНОГО ВТРУЧАННЯ
}

\author{
М. І. Кравців, О. М. Люлька, В. І. Ляховський \\ Українська медична стоматологічна академія, м. Полтава \\ MANAGEMENT OF SURGICAL INCICION AREA INFECTION
}

\author{
M. I. Kravtsiv, O. M. Liulka, V. I. Liakhovskyy \\ Ukrainian Medical Stomatological Academy, Poltava
}

Реферат

Узагальнені результати лікування 26 хворих, у яких після оперативного втручання виникло нагноєння лапаротомної рани. Комплексне лікування з використанням метаболітотропної терапії сприяло більш швидкому загоєнню ран та ерадикації патогенної мікрофлори.

Ключові слова: операції на органах черевної порожнини; інфікування операційної рани; місцеве лікування; метаболітотропна терапія.

Abstract

The results of treatment of 26 patients who suffered from suppuration of surgical wound after operation have been summarized. Complex treatment including metabolic medication resulted in quicker healing of the wound and eradication of pathogenic microorganisms.

Keywords: abdominal surgery; infected surgical wound; local treatment; methabolic therapy.

Проблема післяопераційних гнійно-запальних ускладнень актуальна, особливо в невідкладній абдомінальній хірургії [1]. Найбільш частими ускладненнями післяопераційного періоду є запальні, зокрема, нагноєння операційної рани, що спостерігають у 2 - 30\% хворих. Частота нагноєння лапаротомної рани максимальна після операцій, що супроводжуються порушенням цілісності порожнистих органів, а також при гнійно-запальних захворюваннях органів черевної порожнини $[2,3]$.

Важливу роль в успішному лікуванні нагноєння лапаротомної рани на всіх стадіях перебігу відіграє місцеве лікування $[4,5]$.

Мета дослідження: покращити результати лікування нагноєння лапаротомної рани.

\section{МАТЕРІАЛИ I МЕТОДИ ДОСЛІДЖЕННЯ}

Обстежені 26 хворих віком від 36 до 72 років, яких лікували в хірургічних відділеннях 2-ї Міської клінічної лікарні м. Полтави в період 3 2013 по 2016 р., у яких після операції виникло нагноєння лапаротомної рани. Невідкладні операції з приводу гангренозно-перфоративного апендициту виконані у 5 (19,2\%) хворих, перфоративної виразки шлунка та дванадцятипалої кишки (ДПК) - у
4 (15,4\%), виразки, ускладненої кровотечею - у 3 (11,5\%), гострої непрохідності кишечнику (ГНК) - у 7 (26,9\%), інфікованого панкреонекрозу - у 3 (11,5\%), гострого деструктивного холециститу - у 3 (11,5\%), травми черевної порожнини - в 1 $(3,8 \%)$.

Хворі рандомізовані на дві групи: контрольну - 12 хворих (жінок -7 , чоловіків - 5) та основну - 14 хворих (жінок - 8, чоловіків - 6). За віком, статтю, нозологічними формами та тяжкістю стану хворих групи репрезентативні.

У комплексі лікування хворим, поряд $з$ антибактеріальною терапією, яку призначали 3 огляду на чутливість мікрофлори, протизапальною, інфузійною, симптоматичною та органотропною терапією, проводили місцеве лікування, що передбачало накладення гідрофільних пов'язок. Мазеві пов'язки накладали після попередньої хірургічної обробки ран та адекватного розкриття гнійника щодня 1 - 2 рази на добу, після санації поверхні рани. У 14 пацієнтів (основна група) застосовували комплексне лікування у поєднанні 3 комбінованою метаболітотропною терапією: внутрішньовенно крапельно вводили фосфатидилхолінові ліпосоми - препарат «Ліпін» (500 мг на добу у 50 мл ізотонічного розчину натрію хлориду) та метаболітотроп- ний препарат «Мексидол» (250 мг на добу у 200 мл ізотонічного розчину натрію хлориду) протягом 10 діб. Додатково 1 раз на добу на 5 - 6 год в рану вводили серветку, просочену мексидол-ліпосомальною сумішшю, яку готували безпосередньо перед використанням: до 50 мл ізотонічного розчину натрію хлориду додавали 500 мг ліпіну та 250 мг мексидолу, інтенсивно струшували протягом 3 - 5 хв до утворення однорідної суспензіі.

У 12 хворих (контрольна група) використовували лише загальноприйняте лікування.

Дози препаратів в обох групах визначали за обширністю ураження. Місцеве лікування проводили до повного загоєння рани вторинним натягом чи накладання вторинних швів.

Ефективність лікування оцінювали на підставі суб'єктивних відчуттів пацієнта, результатів досліджень характеру і динаміки показників загоєння ран (наявність виділень, ступінь грануляцій та епітелізаціi). Швидкість загоєння ран (V) обчислювали за формулою: V = (S1S2) × 100 / S1 × t, де S1 - вихідна площа рани; S2 - площа рани після лікування; $\mathrm{t}$ - кількість діб між вимірами [6]. Площу рани визначали за допомогою камери смартфона iPhone 6S та програми MOWA (mobile 
wound analyzer) для iOS 9. В динаміці досліджували кількісний і якісний склад мікрофлори до початку лікування, на 5-ту і 10-ту добу лікування. Методи дослідження стандартні [7].

Статистична обробка одержаних результатів проведена за допомогою пакетів прикладних програм Statistica 7 (StatSoft), SPSS for Windows 16,0 (SPSS inc.) на персональному комп'ютері.

\section{РЕЗУЛЬТАТИ}

\section{TA ÏХ ОБГОВОРЕННЯ}

Аналізуючи клінічні зміни під час загоєння ран, ми встановили, що, порівняно з контрольною групою, больовий синдром у хворих основної групи тривав у середньому на 1,4 доби менше ( $<<0,001)$, набряк навко-

\section{ЛITEPATУPA/REFERENCES}

1. Radzikhovskyi AP, Myronenko OI, Siuta LO, ta in. Faktory vynyknennia ranovoi khirurhichnoi infektsii. Klinichna khirurhiia. 2007;(1112):52. [In Ukrainian].

2. Zhebrovskiy VV. Rannie i pozdnie posleoperatsionnye oslozhneniya $v$ khirurgii organov bryushnoy polosti. Kiev: Izdatelskiy tsentr KGMU, 2000. 687 s. [In Russian].

3. Milonov OB, Toskin KD, Zhebrovskiy VV. Posleoperatsionnye oslozhneniya i opasnosti v abdominalnoy khirurgii. Moskva: Meditsina, 1990. 559 s. [In Russian]

4. Ivanova YuV, Logachev VK. Mestnoe lechenie posleoperatsionnykh gnoyno-vospalitelnykh oslozhneniy. Kharkivska khirurgichna shkola. 2012;3(54):92-4. [In Russian]. лоранових тканин - на 2,1 доби (р $<0,001)$, очищення ран відбулося на $2,5$ доби швидше ( $\mathrm{p}=0,001)$, активні грануляції з'явилися на 3,14 доби раніше ( $<$ 0,001), строки загоєння ран на 4,23 доби менше ( $\mathrm{p}=0,001)$.

планіметричного до-

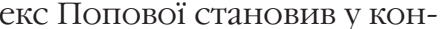
-ту добу - відповідно $(09,59 \pm$ (15,74 $\pm 2,51) \%(p<0,001)$ свідчили, що використанхірургічного втручання сприяло ню загоєння ран.
За результатами мікробіологічного дослідження виділень 3 рани у хворих обох груп виявлені такі основні збудники: E. coli, S. aureus, P. aeruginosa, Klebsiella, а також асоціації E. coli 3 S. aureus, E. coli 3 Proteus spp. Отже, ранова інфекція після оперативного втручання на органах черевної порожнини спричинена частіше E. coli в монокультурі - у 38,5\% спостережень, в асоціації 3 S. aureus i Proteus spp. - у 23,1\%.

На 5-ту добу лікування у 77\% пацієнтів вдалося досягти повної ерадикації збудників, до 10-ї доби аеробна мікрофлора в рані не виявлена у жодного пацієнта.
5. Datsenko BM. Ranevoy protsess kak fundamentalnaya problema sovremennoy klinicheskoy khirurgii. Visnik Ukraïnskoy medichnoy stomatologichnoy akademiy. Aktualni problemi suchasnoï meditsini. 2007;1-2(17-18):212-4. [In Russian].

6. Abaev YuK. Spravochnik khirurga. Rany i ranevaya infektsiya. Rostov - na - Donu : Feniks, 2006. 427 s. [In Russian].

7. Pozdeev OK, Pokrovskiy VI. Meditsinskaya mikrobiologiya. Moskva: GEOTAR Meditsina, 2001. 765 s. [In Russian]. 